\title{
Metastatic Lung Squamous Cell Carcinoma
}

National Cancer Institute

\section{Source}

National Cancer Institute. Metastatic Lung Squamous Cell Carcinoma. NCI Thesaurus. Code C156092.

A squamous cell carcinoma that arises from the lung and has metastasized to another anatomic site. 